\title{
VARIATION IN THE PROPERTIES OF A STRAIN OF STAPHYLOCOCCUS AUREUS ISOLATED OVER THREE MONTHS FROM A SINGLE HOSPITAL
}

\author{
R. W. LACEY*, Evelyn Lewis* aNd Joy HaRRISON $\dagger$ \\ Departments of Bacteriology, ${ }^{*}$ University of Bristol and \\ $\dagger$ Frenchay Hospital, Bristol
}

EvolutionaRY change in an organism may be predicted from two lines of evidence: $(a)$ experiments performed in the laboratory that show the potential change in vivo; and $(b)$ the characterisation of changes that have occurred in a few organisms in nature. In Staphylococcus aureus, experiments in vitro demonstrate that mutation to resistance to a few antibiotics can occur at frequencies of $10^{-7}-10^{-10}$, and that a variety of plasmids may be lost from or gained by the cell, although there seems to be a limit to the number of plasmids that an organism can maintain stably (Lacey and Chopra, 1974). We have found that plasmid genome can also be lost from a strain in vivo at high frequency (Lacey, Lewis, and Grinsted, 1973; Lacey, Lewis, and Rosdahl, 1974) and that one plasmid has been gained by several different staphylococci in nature (Lacey and Rosdahl, 1974). Rather few clinical strains appear to have gained resistance to antibiotics by mutation, apart from resistance to streptomycin (Lacey and Chopra, 1972).

It seems therefore that most of the processes that can occur in vitro have also occurred in vivo. There is, however, little information as to the frequency of occurrence of several of these phenomena in vivo. Methicillin-resistant staphylococci possess several characteristic properties (Lacey and Grinsted, 1973); we have used these markers to identify "one" staphylococcus from a hospital over 3 months. Although in some instances we cannot be certain of the direction of the evolutionary change in this clone (i.e., the variation in the carriage of some plasmids in these isolates might be due to gain or loss of the element), the results presented here strengthen the concept of very rapid evolution in the staphylococcus in nature. There seems little doubt that recently isolated organisms have evolved from strains that were endemic previously, and are not " new" strains selected by the use of novel antibiotics. The implications of some of these findings for antibiotic strategy are also considered.

\section{MATERIALS AND METHODS}

Staphylococci. Of the 28 cultures examined, 27 were obtained from hospital patients or nurses with clinical evidence of infection; the remaining isolate was from a nasal carrier. The isolates were obtained between early September and early December 1973. Most of the cultures were obtained from patients in a plastic-surgery-and-burns unit (all the D numbers, 
see table I), and the remainder from patients or nurses in other wards, in Frenchay Hospital, Bristol. Before the isolation of the strains, several of the patients had been treated with a variety of antibiotics-clindamycin, ampicillin, penicillin, gentamicin, cephaloridine, flucloxacillin, and co-trimoxazole.

Antibiotic sensitivity was determined as previously (Lacey et al., 1974), including the identification of resistance to erythromycin or lincomycin as either inducible or constitutive. Sensitivity to sulphonamide, trimethoprim, and co-trimoxazole was tested by the method of Lewis and Lacey (1973). The reaction to methicillin was obtained by diluting overnight cultures of each isolate (grown at $37^{\circ} \mathrm{C}$ ), to $10^{-2}$ and $10^{-4}$, plating the neat and diluted cultures in duplicate on nutrient-agar plates containing concentrations of methicillin, and incubating these at $30^{\circ} \mathrm{C}$ or $37^{\circ} \mathrm{C}$. All the "methicillin-resistant" isolates showed heterogeneous resistance to methicillin-i.e., only 1 coccus in about $10^{6}$ was highly resistant to methicillin at $37^{\circ} \mathrm{C}$, whilst at $30^{\circ} \mathrm{C}$ every coccus was resistant.

Bacteriophage typing was done at routine test dilution (RTD).

Transduction procedure was essentially that of Lacey (1972). Lysates were prepared by propagation of typing phage 88 in three successive cycles by the freeze-thawing method of Williams and Rippon (1952). Before the first propagation, cultures were heated to $50^{\circ} \mathrm{C}$ for $2 \mathrm{~min}$. and then seeded on to nutrient-agar plates. The recipient was strain no. 649 (Grinsted and Lacey, 1973). Irradiation of the lysate by ultra-violet (UV) light was by the method described previously (Lacey, 1972).

Replica plating was as described (Lacey, 1972); several antibiotics were combined into one medium. Loss of the "penicillinase plasmid" was investigated by replica plating on medium containing $10^{-4} \mathrm{M}$ cadmium acetate.

TABLE I

Properties common to all isolates of a strain of Staphylococcus aureus obtained from a hospital over three months

\begin{tabular}{|c|c|c|c|c|c|c|}
\hline \multirow[b]{2}{*}{$\begin{array}{l}\text { Isolate } \\
\text { number }\end{array}$} & \multirow[b]{2}{*}{$\begin{array}{c}\text { Phage typing } \\
\text { pattern (RTD)* }\end{array}$} & \multicolumn{5}{|c|}{ Minimum inhibitory concentrations of } \\
\hline & & $\begin{array}{l}\text { streptomycin } \\
(\mathrm{mg} \text { per } \mathrm{ml} \text { ) }\end{array}$ & $\begin{array}{l}\text { tetracycline } \\
(\mu \mathrm{g} \text { per } \mathrm{ml})\end{array}$ & $\begin{array}{c}\text { sulphamethoxazole } \\
(\mu \mathrm{g} \text { per ml) }\end{array}$ & $\begin{array}{c}\text { trimethoprim } \\
(\mu \mathrm{g} \text { per } \mathrm{ml})\end{array}$ & $\begin{array}{c}\text { co-trimoxazole } \\
\text { (trimethoprim/ } \\
\text { sulphamethoxazole, } \\
\mu \mathrm{g} \text { per ml) }\end{array}$ \\
\hline $\begin{array}{l}\text { D158 } \\
\text { D159 } \\
\text { D160 } \\
\text { D161(1)† } \\
\text { D161(2) } \\
\text { D161(3) } \\
\text { D161(4) } \\
\text { D162 } \\
\text { D167 } \\
\text { D168 } \\
\text { F59 } \\
\text { D189 } \\
\text { D191 } \\
\text { D194 } \\
\text { D213 } \\
\text { D214 } \\
\text { D215 } \\
\text { B68 } \\
\text { B69 } \\
\text { D218 } \\
\text { D223 } \\
\text { B71 } \\
\text { C112 } \\
\text { D235 } \\
\text { D237 } \\
\text { D249 } \\
\text { D252 } \\
\text { F63 }\end{array}$ & 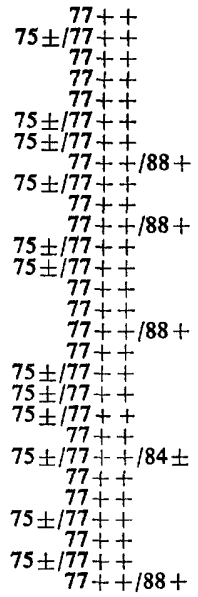 & $\begin{array}{l}>10 \\
>10 \\
>10 \\
>10 \\
>10 \\
>10 \\
>10 \\
>10 \\
>10 \\
>10 \\
>10 \\
>10 \\
>10 \\
>10 \\
>10 \\
>10 \\
>10 \\
>10 \\
>10 \\
>10 \\
>10 \\
>10 \\
>10 \\
>10 \\
>10 \\
>10 \\
>10 \\
>10\end{array}$ & $\begin{array}{l}200 \\
200 \\
200 \\
100 \\
200 \\
200 \\
200 \\
50 \\
200 \\
200 \\
200 \\
200 \\
200 \\
200 \\
200 \\
100 \\
200 \\
200 \\
200 \\
200 \\
200 \\
200 \\
200 \\
200 \\
200 \\
200 \\
200 \\
100\end{array}$ & $\begin{array}{l}100 \\
100 \\
100 \\
100 \\
400 \\
100 \\
100 \\
100 \\
100 \\
100 \\
200 \\
400 \\
100 \\
100 \\
200 \\
200 \\
50 \\
100 \\
100 \\
100 \\
100 \\
100 \\
100 \\
200 \\
100 \\
100 \\
100 \\
100\end{array}$ & 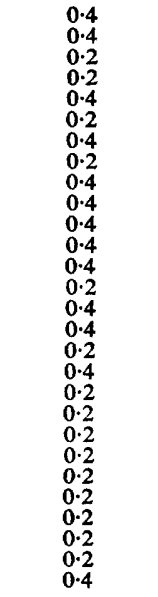 & $\begin{array}{l}0 \cdot 1 / 2 \\
0 \cdot 1 / 2 \\
0 \cdot 1 / 2 \\
0 \cdot 1 / 2 \\
0 \cdot 1 / 2 \\
0 \cdot 1 / 2 \\
0 \cdot 1 / 2 \\
0 \cdot 2 / 4 \\
0 \cdot 1 / 2 \\
0 \cdot 1 / 2 \\
0 \cdot 1 / 2 \\
0 \cdot 1 / 2 \\
0 \cdot 1 / 2 \\
0 \cdot 1 / 2 \\
0 \cdot 2 / 4 \\
0 \cdot 2 / 4 \\
0 \cdot 1 / 2 \\
0 \cdot 1 / 2 \\
0 \cdot 1 / 2 \\
0 \cdot 1 / 2 \\
0 \cdot 1 / 2 \\
0 \cdot 1 / 2 \\
0 \cdot 1 / 2 \\
0 \cdot 1 / 2 \\
0 \cdot 1 / 2 \\
0 \cdot 1 / 2 \\
0 \cdot 1 / 2 \\
0 \cdot 1 / 2\end{array}$ \\
\hline
\end{tabular}

* $\mathbf{R T D}=$ Routine test dilution.

$\dagger=$ Four different colonies obtained from same patient. 


\section{RESULTS}

\section{Properties of a staphylococcus isolated from a hospital over three months}

Preliminary testing of a proportion of all isolates of Staphylococcus aureus from the hospital showed that about $40 \%$ were lysed by phage 77 at RTD, and that some of these gave weak reactions with other phages. The strains that gave a reaction with phage 77 were examined further and, on the basis of phage-typing pattern, and of resistance or sensitivity to streptomycin, tetracycline, sulphonamide and trimethoprim, 28 isolates were considered the "same" strain (table I). Most of the isolates showed heterogeneous resistance to methicillin, and the level of resistance to streptomycin (MIC >10 $\mathrm{mg}$ per ml) and tetracycline (MIC in most instances $200 \mu \mathrm{g}$ per ml) was similar to other methicillin-resistant staphylococci (Lacey and Grinsted, 1973). The reaction to sulphonamides (MIC 100-400 $\mu \mathrm{g}$ per $\mathrm{ml}$ ) was distinct and unusual, being intermediate between that of most sensitive (MIC $<20 \mu \mathrm{g}$ per $\mathrm{ml}$ ) and resistant staphylococci (MIC $>1000 \mu \mathrm{g}$ per ml) (e.g., Lewis and Lacey, 1973). A further

TABLE II

Variations in properties of isolates of a strain of Staphylococcus aureus obtained from a hospital over three months

\begin{tabular}{|c|c|c|c|c|c|}
\hline \multirow{2}{*}{ Isolate number } & \multicolumn{5}{|c|}{ Results* of sensitivity tests with } \\
\hline & methicillin & neomycin & penicillin & erythromycin & lincomycin \\
\hline $\begin{array}{l}\text { D158 } \\
\text { D159 } \\
\text { D160 } \\
\text { D161(1) } \\
\text { D161(2) } \\
\text { D161(3) } \\
\text { D161(4) } \\
\text { D162 } \\
\text { D167 } \\
\text { D168 } \\
\text { F59 } \\
\text { D189 } \\
\text { D191 } \\
\text { D1944 } \\
\text { D213 } \\
\text { D214 } \\
\text { D215 } \\
\text { B68 } \\
\text { B69 } \\
\text { D218 } \\
\text { D223 } \\
\text { B71 } \\
\text { C112 } \\
\text { D235 } \\
\text { D237 } \\
\text { D249 } \\
\text { D252 } \\
\text { F63 }\end{array}$ & $\begin{array}{l}R \\
R \\
R \\
R \\
R \\
R \\
R \\
R \\
R \\
R \\
R \\
R \\
R \\
R \\
R \\
R \\
R \\
R \\
S \\
R \\
R \\
R \\
S \\
R \\
R \\
S \\
R \\
R \\
R \\
R\end{array}$ & $\begin{array}{l}\mathbf{R} \\
\mathbf{R} \\
\mathbf{R} \\
\mathbf{R} \\
\mathbf{R} \\
\mathbf{R} \\
\mathbf{R} \\
\mathbf{R} \\
\mathbf{R} \\
\mathbf{R} \\
\mathbf{R} \\
\mathbf{R} \\
\mathbf{R} \\
\mathbf{R} \\
\mathbf{R} \\
\mathbf{R} \\
\mathbf{R} \\
\mathbf{S} \\
\mathbf{S} \\
\mathbf{S} \\
\mathbf{R} \\
\mathbf{S} \\
\mathbf{S} \\
\mathbf{R} \\
\mathbf{S} \\
\mathbf{R} \\
\mathbf{S} \\
\mathbf{R}\end{array}$ & $\begin{array}{l}+ \\
+ \\
\pm \\
+ \\
+ \\
+ \\
+ \\
+ \\
+ \\
+ \\
+ \\
+ \\
+ \\
+ \\
+ \\
+ \\
+ \\
+ \\
+ \\
+ \\
+ \\
+ \\
+ \\
+ \\
+ \\
+ \\
+\end{array}$ & $\begin{array}{l}R(C) \\
R(C) \\
R(I) \\
R(I) \\
R(C) \\
R(I) \\
R(C) \\
R(I) \\
R(C) \\
R(C) \\
R(I) \\
R(I) \\
R(C) \\
R(C) \\
R(I) \\
R(I) \\
R(I) \\
S \\
S \\
S \\
R(I) \\
S \\
\text { R(I) } \\
R(I) \\
\text { S } \\
\text { R(I) } \\
S \\
R(I)\end{array}$ & $\begin{array}{l}R(C) \\
R(C) \\
S \\
S \\
R(C) \\
S \\
S \\
R(C) \\
S \\
R(C) \\
R(C) \\
S \\
S \\
S(C) \\
R(C) \\
R(C) \\
S \\
S \\
S \\
S \\
S \\
S \\
S \\
S \\
S \\
S \\
S \\
S \\
S \\
S \\
S\end{array}$ \\
\hline
\end{tabular}

* $\mathrm{R}=$ resistant; $\mathrm{R}(\mathrm{C})=$ constitutive resistance; $\mathrm{R}(\mathrm{I})=$ inducible resistance; $\mathrm{S}=$ sensitive; $+=$ penicillinase producer; $-=$ penicillinase-negative. 
feature of these isolates was that none showed marked bacteristatic synergy between trimethoprim and sulphonamides (table 1). These isolates are all evidently very similar and are probably derived from the "methicillin-resistance" clone (Lacey and Grinsted, 1973). The formal possibility that these strains represent convergent evolution, i.e., that several initially distinct organisms have evolved to the same type, seems extremely unlikely.

\section{Variation in properties of the staphylococcal strain}

The 28 isolates showed variation in their resistance to methicillin, penicillin (penicillinase), neomycin (MIC $0.25 \mu \mathrm{g}$ per ml when sensitive; $>4 \mu \mathrm{g}$ per ml when resistant), erythromycin, and lincomycin (table II). The MICs of the four methicillin-sensitive isolates to methicillin were of the same order as other methicillin-sensitive staphylococci $(2-5 \mu \mathrm{g}$ per $\mathrm{ml})$ at $30^{\circ} \mathrm{C}$, at $37^{\circ} \mathrm{C}$, and in the presence of $5 \%(\mathrm{w} / \mathrm{v}) \mathrm{NaCl}$. Attempts to restore methicillin resistance in these four isolates were unsuccessful; in these experiments about $5 \times 10^{12}$ cells of each culture were plated on to the surface of agar plates containing methicillin $25 \mu \mathrm{g}$ per $\mathrm{ml}$ and incubated for $72 \mathrm{~h}$ at $30^{\circ} \mathrm{C}$. Colonies that showed heterogeneous resistance to methicillin were not detected. Because methicillin resistance does not appear to arise de novo and can be transduced to recipients in vitro only at low frequency if at all (Lacey, 1972), it seems very likely that the variation in methicillin resistance of these isolates is due to loss rather than gain of the relevant genes. The inability to restore the resistance is consistent with the loss of a large region of genome (possibly an entire plasmid) from the cell, as seems to occur in vitro (Lacey, 1972).

The variation in penicillinase production and in neomycin resistance is probably due to loss of the relevant genes, although there seems no way of establishing this with certainty. It is also conceivable that the isolates that were unable to form penicillinase and the seven neomycin-sensitive cultures had lost the genes in vitro, but this seems unlikely because both of these markers were relatively stable in vitro in other isolates of these staphylococci (see below).

The reaction of the isolates to erythromycin and lincomycin gave three patterns: six were sensitive to both antibiotics (MIC $<0.5 \mu \mathrm{g}$ per $\mathrm{ml}$ for each), 14 showed inducible resistance to erythromycin but were sensitive to lincomycin, and eight showed constitutive resistance to both lincomycin and erythromycin (MIC $\sim 1000 \mu \mathrm{g}$ per $\mathrm{ml}$ for each). These latter two patterns resemble those in another staphylococcal clone (Lacey, Lewis and Rosdahl, 1974). Attempts to isolate one-step lincomycin-resistant mutants from isolates of the strain under investigation gave variable success. From four cultures that showed inducible resistance to erythromycin, mutation to high-level resistance to lincomycin (MIC $1000 \mu \mathrm{g}$ per ml) occurred at frequencies of about 10-7-10-9. But with four cultures that were sensitive to both erythromycin and lincomycin (and also with 10 unrelated sensitive strains), mutants resistant to erythromycin or lincomycin $100 \mu \mathrm{g}$ per ml were not obtained from about $10^{12}$ cocci of each culture. Two lincomycin-resistant mutants from each of strains F63 and D162 (table I) were subcultured twice in antibiotic-free medium and 
then examined for the nature of their resistance to lincomycin and erythromycin. All four colonies showed high-level constitutive resistance to both antibiotics. It seems probable, therefore, that the clinical strains that possessed constitutive resistance to both lincomycin and erythromycin had acquired a mutation in vivo in a way similar to strain FAR4 (Lacey et al., 1974). The genes coding for constitutive resistance to lincomycin and erythromycin in mutant cultures F63 and D162 are probably linked to those determining inducible resistance to erythromycin on the following evidence. Transductants obtained by selecting for either lincomycin resistance from the mutants, or inducible resistance to erythromycin from the clinical strains, were also resistant to spectinomycin; most erythromycin-resistant staphylococci are also resistant to spectinomycin (Grinsted and Lacey, 1973). Transduction kinetics indicated that these genes are probably plasmid-borne in strain D162 (see below).

\section{Location of genes in the staphylococci}

The location of genes for antibiotic resistance was investigated in strains D162, D194 and D215 by testing the stability of the resistances at $43^{\circ} \mathrm{C}$ and by examination of the transduction kinetics. The absence of any stimulation in the transduction frequency by exposure of the lysate to UV light is strong evidence for a plasmid locus for the gene in question, although some of the

TABLE III

Stability of markers in cultures D162, D194 and D215 after growth at $42^{\circ} \mathrm{C}$ and effect of $U V$ treatment of the lysate on the transduction frequency of each marker

\begin{tabular}{|c|c|c|c|c|c|}
\hline $\begin{array}{l}\text { Culture } \\
\text { number }\end{array}$ & Marker* & $\begin{array}{l}\text { Number of } \\
\text { colonies } \\
\text { tested }\end{array}$ & $\begin{array}{l}\text { Number of sensitive } \\
\text { colonies after } \\
\text { growth at } 42^{\circ} \mathrm{C}\end{array}$ & $\begin{array}{l}\text { Maximum stimulation } \\
\text { of transduction } \\
\text { frequency by UV light }\end{array}$ & $\begin{array}{l}\text { Probable } \\
\text { locus of } \\
\text { gene }\end{array}$ \\
\hline D162 & $\begin{array}{l}\text { str } \\
\text { tet } \\
\text { mtc } \\
\text { ero } \\
\text { neo } \\
\text { cad }\end{array}$ & $\begin{array}{l}2700 \\
2700 \\
2700 \\
2700 \\
2700 \\
2700\end{array}$ & $\begin{array}{l}0 \\
0 \\
0 \\
0 \\
8 \\
0\end{array}$ & $\begin{array}{l}\times 14 \\
\times 1.2 \\
\quad N T \dagger \\
\times<1.0 \\
\times<1.0 \\
\times<1.0\end{array}$ & $\begin{array}{l}\text { Chromosomal } \\
\text { Plasmid } \\
? \\
\text { Plasmid } \\
\text { Plasmid } \\
\text { Plasmid }\end{array}$ \\
\hline D194 & $\begin{array}{l}\text { str } \\
\text { tet } \\
\text { mtc } \\
\text { ero } \\
\text { neo } \\
\text { cad }\end{array}$ & $\begin{array}{l}3500 \\
3500 \\
3500 \\
3500 \\
3500 \\
3500\end{array}$ & $\begin{array}{l}0 \\
0 \\
0 \\
0 \\
2 \\
0\end{array}$ & $\begin{array}{l}x 12 \\
\times<1.0 \\
\text { NT } \\
\times<1.0 \\
\times<1.0 \\
\times<1.0\end{array}$ & $\begin{array}{l}\text { Chromosomal } \\
\text { Plasmid } \\
? \\
\text { Plasmid } \\
\text { Plasmid } \\
\text { Plasmid }\end{array}$ \\
\hline D215 & $\begin{array}{l}\text { str } \\
\text { tet } \\
\text { ero } \\
\text { neo } \\
\text { cad }\end{array}$ & $\begin{array}{l}2500 \\
2500 \\
2500 \\
2500 \\
2500\end{array}$ & $\begin{array}{l}0 \\
0 \\
0 \\
2 \\
2\end{array}$ & $\begin{array}{r}\times 17 \\
\times 1.4 \\
\times<1.0 \\
\times<1.0 \\
\times<1.0\end{array}$ & $\begin{array}{l}\text { Chromosomal } \\
\text { Plasmid } \\
\text { Plasmid } \\
\text { Plasmid } \\
\text { Plasmid }\end{array}$ \\
\hline
\end{tabular}

* $s t r=$ Resistance to streptomycin, tet to tetracycline, $m t c$ to methicillin, ero to erythromycin neo to neomycin, cad to cadmium ions.

$\dagger \mathrm{NT}=$ no transductants detected. 
resistances were stable (table III). The UV-stimulation of transduction of streptomycin resistance (table III) is consistent with a chromosomal locus for the gene, although transduction frequency of some plasmid genes may show a moderate degree of UV-stimulation (Rubin and Rosenblum, 1971). However, streptomycin resistance in these strains was stable and its level (MIC>10 mg per $\mathrm{ml}$ ) also favoured a chromosomal locus for the genes (Grinsted and Lacey, 1973).

Thus, strains D162 and D194 both appear typical methicillin-resistant strains, possessing chromosomal resistance to streptomycin, stable plasmidmediated resistance to tetracycline, and plasmid-mediated resistance to other antibiotics (Lacey and Grinsted, 1973). These cultures also resembled other methicillin-resistant staphylococci in that the methicillin resistance was not transducible to an antibiotic-sensitive recipient (Lacey, 1972).

Culture D215 differs from cultures D162 and D194 only in its sensitivity to methicillin (tables I and II). Furthermore, the location of several genes in culture D215 was the same as in cultures D162 and D194 (table III). This is consistent with the proposal (see above) that culture D215 has evolved from a clone of the D162-D194 type by the loss of genes for methicillin resistance.

\section{Discussion}

The phenotypic properties of all and the genetic analysis of a few of the 28 isolates of the staphylococcus that we have examined suggest that all are essentially the same strain. Most if not all of the changes that have occurred in this strain probably occurred in vivo. We have observed previously rapid evolution of a type 3A strain (Lacey, Lewis and Rosdahl, 1974); the findings presented here show that another strain has also evolved rapidly, and we consider that this type of change is probably general in this organism. Thus, many of the manipulations performed in the laboratory are reflected in natural events, and these changes occur rapidly. Future antibiotic strategy should take this into account.

The therapeutic implications of this study are two-fold: first the loss of methicillin resistance seen in four of the isolates is consistent with the possibility that this resistance may not be clinically important (Lacey, 1974). If methicillin resistance was of value to the cell in vivo by protecting it against all the penicillins and cephalosporins, the genes for methicillin-resistance should have been retained, because there was no restriction in the use of these antibiotics in the hospital before the isolation of the cultures.

The second implication concerns the use of erythromycin and lincomycin and their analogues. There have been several reports of resistance to lincomycin arising during treatment with this drug (Duncan, 1968; McGehee, Barrett and Finland, 1969; Wright and Harper, 1970). Mutation to lincomycin resistance does not apparently confer any disadvantage to the cell (Lacey et al., 1974). As far as we are aware, nearly all lincomycin-resistant clinical isolates of Staphylococcus aureus are also resistant to erythromycin. Our genetic studies provide an explanation for this. The gene that is capable 
of mutating to confer lincomycin resistance is adjacent to that coding for inducible erythromycin resistance (this paper; Lacey et al., 1974). We have been unable to select in one step mutants resistant to high levels of lincomycin from erythromycin-sensitive staphylococci; and although lincomycin resistance may be developed by "training" experiments in vitro, there is no evidence that bacteria develop it by this process in nature. Thus it would seem that there is a serious risk that staphylococci that are already resistant to erythromycin will acquire lincomycin resistance when exposed to the drug. Furthermore, this mutation causes a change in the nature of erythromycin resistance from inducible (when only a minority of cells are resistant without prior exposure to the drug) to constitutive (all the cells are inherently highly resistant). It is possible that, in some situations, this change could prevent the elimination of the organism by erythromycin or analogue.

Thus, unless lincomycin or clindamycin are shown to be convincingly superior to erythromycin against sensitive organisms, it would seem desirable to limit the use of lincomycin and clindamycin against Staphylococcus aureus. Erythromycin is of value in the treatment of infections caused by erythromycinsensitive staphylococci, and a drug other than erythromycin or lincomycin should be used against erythromycin-resistant bacteria.

\section{SUMMARY}

A strain of Staphylococcus aureus has been isolated from a hospital environment over 3 months. Every isolate was lysed by phage 77, had high-level resistance to streptomycin, and was resistant to about $250 \mu \mathrm{g}$ per ml of both tetracycline and sulphonamide; a combination of sulphamethoxazole and trimethoprim produced little bacteristatic synergy towards each isolate. All these organisms were thus considered to be "the same"; the variation in other properties was probably due to rapid evolutionary change in vivo. The variation in sensitivity to methicillin and neomycin, and the absence of penicillinase production in some isolates, probably indicated loss of the relevant genes. Several isolates had probably acquired resistance to lincomycin by a one-step mutation in vivo. The usefulness of lincomycin and analogues in treating staphylococcal infections seems limited.

We thank Dr V. G. Alder for phage typing.

\section{REFERENCES}

Duncan, I. B. R. 1968. Development of lincomycin resistance by staphylococci. Antimicrob. Agents Chemother. 1967, p. 723.

Grinsted, J. AND LACEY, R. W. 1973. Genetic variation of streptomycin resistance in clinical strains of Staphylococcus aureus. J. med. Microbiol., 6, 351.

LACEY, R. W. 1972. Genetic control in methicillin-resistant strains of Staphylococcus aureus. J. med. Microbiol., 5, 497.

LACEY, R. W. 1974. Can methicillin-resistant strains of Staphylococcus aureus be treated with methicillin? Lancet, 1,88 .

LACEY, R. W. AND CHOPRA, I. 1972. Evidence for mutation to streptomycin resistance in clinical strains of Staphylococcus aureus. J. gen. Microbiol., 73, 175. 
LACEY, R. W. AND ChOPRA, I. 1974. Genetic studies of a multi-resistant strain of Staphylococcus aureus. J. med. Microbiol., 7, 285.

LACEY, R. W. AND GRINSTED, J. 1973. Genetic analysis of methicillin-resistant strains of Staphylococcus aureus; evidence for their evolution from a single clone. $J$. med. Microbiol., 6, 511.

LACEY, R. W., LewIS, E. AND GRINSTED, J. 1973. Loss of antibiotic resistance in Staphylococcus aureus in vivo probably resulting from cloxacillin therapy. J. med. Microbiol., 6, 191.

LACEY, R. W., LEWIS, E. L. AND RosDaHL, V. T. 1974. Evolution of plasmids in vivo in a strain of Staphylococcus aureus. J. med. Microbiol., 7, 117.

LACEY, R. W. AND RoSDAHL, V. T. 1974. An unusual " penicillinase plasmid " in Staphylococcus aureus; evidence for its transfer under natural conditions. J. med. Microbiol., $7,1$.

LeWIS, E. L. AND LACEY, R. W. 1973. Present significance of resistance to trimethoprim and sulphonamides in coliforms, Staphylococcus aureus and Streptococcus faecalis. J. clin. Path., 26, 175.

McGehee, R. F., BarRe, F. F. AND Finland, M. 1969. Resistance of Staphylococcus aureus to lincomycin, Clinimycin and erythromycin. Antimicrob. Agents Chemother., 1968, p. 392.

Rubin, S. J. AND Rosenblum, E. D. 1971. Effects of the recipient strain and ultraviolet irradiation on transduction kinetics of the penicillinase plasmid of Staphylococcus aureus. J. Bact., 108, 1192.

Williams, R. E. O. AND RIPPON, J. E. 1952. Bacteriophage typing of Staphyloccus aureus. J. Hyg., Camb., 50, 320.

Wright, C. L. T. AND HARPER, J. 1970. Fusidic acid and lincomycin therapy in staphylococcal infections in cystic fibrosis. Lancet, 1, 9. 